\title{
DE WORDING VAN HET PHILIPPIJNSCHE REGEERINGSREGLEMENT VAN 1916
}

\author{
DOOR \\ Mr. C. VAN VOLLENHOVEN.
}

I.

\section{De behandeling in het congres.}

Het eerste bij de wet vastgestelde regeeringsreglement der Philippijnen, dat van 1 Juli 1902, in zijn opschrift zelf gekenmerkt als "voorloopig», is, na herhaaldelijk gewijzigd te zijn, in 1916 opgevolgd - men kan niet zeggen : vervangen - door een nieuw regeeringsreglement, het thans geldende. Het dubbele doel dier nieuwe wet van 1916 is geweest, het aandeel der Filipino's in de regeering van hun eigen land op tal van manieren tergrooten, en bovendien bij de wet zelf iets te bepalen over de toekomstige onafhankelijkheid der Philippijnen. "It is not» - gelijk het eens aardig van de Filipino's gezegd is -, "it is not good government that people want. It is self-government. They hope it will be good government. But whether it is good government or not, they want self-government».

De man, die hen in dien strijd het krachtigst heeft bijgestaan in het congres der Vereenigde Staten, is het in April 1917 overleden democratische lid van het huis van afgevaardigden W. A. Jones (Virginia) geweest. Men zou Jones, die van beroep advocaat was en sinds Maart 1912 voorzitter is geweest van de koloniale commissie uit het huis van afgevaardigden (chairman of the Committee on Insular Affairs), den Van Deventer der Philippijnen kunnen noemen - met alle speelruimte voor het zeer wijde verschil tusschen beide mannen -; in de oogen der Filipino's, in elk geval, bekleedt hij een soortgelijke plaats als Van Deventer in de oogen onzer Indonesiërs.

Zijn eerste stap heeft bestaan in het indienen, op 20 Maart 1912, van een wetsontwerp «To establish a qualified indepen- 
dent government for the Philippines and to fix the date when such qualified independence shall become absolute and complete, and for other purposes", - de zoogenaamde Jones bill. Over dit ontwerp is een commissieverslag uitgebracht op 26 April 1912 (democratische meerderheid, vóór) en 29 April 1912 (republikeinsche minderheid, tegen); doch tot openbare behandeling eerst in een Committee of the Whole House on the state of the Union (een openbaar comité-generaal onder een anderen voorzitter dan den speaker van het huis), daarna in het huis zelf is het niet gekomen. Het $62^{\text {ste }}$ congres $(1911-1913)$, bij hetwelk deze wetsvoordracht was ingediend, stierf in Maart 1913, en daarmee verviel het ontwerp. Dit eerste ontwerp-Jones telde 31 artikelen, en behelsde over de onafhankelijkheid de bepaling, eenerzijds (artikelen 2 en 29) dat van 4 Juli 1913 tot 4 Juli 1921 de Philippijnen - onder den naam "Republic of the Philippines» (artikel 4) - een bij deze wet zelf geclausuleerde onafhankelijkheid zouden genieten onder een door Amerika benoemden president en een eigengekozen congres, doch met Amerikaansche bezettingstroepen (artikel 30) en met eenige bevoegdheden voor autoriteiten te Washington, - anderzijds (artikelen 2, 30 en 31) dat zij van 4 Juli 1921 af ten volle onafhankelijk en in het genot van volstrekte buiten- en binnenlandsche souvereiniteit zouden zijn. Reeds van 1913 af zou (artikel 21) de president der Philippijnen gezanten en consuls mogen benoemen en (behoudens goedkeuring der Vereenigde Staten tot 1921 toe) internationale verdragen mogen sluiten. De beweegreden en artikel 28 kenschetsten het ontwerp dan ook niet als een regeeringsreglement, maar "as a constitution for the Philippine Islands", als "the constitution of the Republic of the Philippines», die van 1921 af zou kunnen worden gewijzigd buiten eenig toedoen der Vereenigde Staten om.

De tweede stap bestond in de indiening van een belangrijk getemperd ontwerp-Jones op 11 Juli 1914; de democraten waren inmiddels, met president Wilson (Maart 1913), tot de hoogste regeermacht gekomen. Het is dit tweede ontwerp-Jones, dat geleid heeft - langs een zeer bochtigen weg - tot de wet van 1916. Wie het lotgeval dier voordracht van 1914 af tot begin 1916 toe (dus tot vóór het laatste bedrijf) wil kennen in zijn groote lijnen, vindt een helder, vurig en onderhoudend geschreven relaas in The case for the Filipinos, door den jongen 
Filipino M. M. Kalau (New York, 1916), blz. 204-245. In het hiervolgend opstel daarentegen is het slechts te doen om een nauwkeurige, naakte weergave van de feiten, die, wegens haar verwardheid, dikwijls zijn misverstaan.

$\mathrm{Na}$ een commissieverslag van 26 Augustus 1914 (democratische meerderheid, vóór) en 31 Augustus 1914 (republikeinsche minderheid, tegen) was het tweede ontwerp-Jones in openbare behandeling bij het huis van afgevaardigden tusschen 26 September en 14 October 1914. Ten aanzien van de onafhankelijkheid was niets bepaald in de 29 artikelen van dit tweede ontwerp; en de beweegreden verklaarde als het doel der Vereenigde Staten nu niet langer - als die van 1912 - " to permit said people to establish for themselves an independent government", maar "to recognize their independence as soon as a stable government can be established therein». Van een Philippijnsche republiek met een president, gezanten, consuls en internationale verdragen was geen sprake meer, evenmin als van een kenschetsing van het ontwerp als grondwet (constitution) der Philippijnen; en zulks niettegenstaande de voorsteller zelf en het meerderheidsverslag erkend hadden, dat de Filipino's er tusschen 1912 en 1914 in bekwaamheid tot zelfregeering op waren vooruitgegaan.

Bij de behandeling van dit ontwerp in het huis van afgevaardigden is aan de artikelen en hun redactie behoorlijk aandacht gegeven; ook zijn tal van amendementen voorgesteld. Zakelijks is er in het wetsontwerp nochtans niet veel veranderd: de godsdienstige neutraliteit der overheid is veel scherper geformuleerd (in artikel 3), en de zittingstijd der leden van beide huizen werd van vier op zes jaar gebracht (artikelen 13 enz.), evenals die der beide koloniale hulpafgevaardigden of Resident Commissioners in het congres te Washington (artikel 20). Een amendement voor vrouwenkiesrecht werd verworpen met 84 tegen 58 stemmen; een amendement voor het verbod van sterken drank werd door den voorzitter in den vorm, waarin het was voorgedragen, ontoelaatbaar verklaard. $\mathrm{Na}$ af handeling in openbaar comité-generaal op 14 October 1914 werd dit tweede ontwerp-Jones dien zelfden dag in het huis zelf aangenomen met 212 stemmen (alle democratische stemmen, plus een paar republikeinsche) tegen 60 (republikeinsche).

Op 15 October 1914 ging het wetsontwerp aldus naar den senaat. Een afdoening door den senaat was van te grooter 
gewicht, omdat het $63^{\text {ste }}$ congres $(1913-1915)$ zou sterven in Maart 1915, en omdat derhalve dit tweede ontwerp-Jones, indien het niet vóór dien tijd was aangenomen, den weg zou opgaan van het eerste ontwerp. De tweede kamer (of volksraad) van het Philippijnsche parlement benevens de toenmalige Philippijnsche commissie (de landvoogd in rade, tevens eerste kamer) te Manila namen dan ook een gemeenschappelijke resolutie aan om den senaat tot afdoening aan te sporen; doch op de vierweeksche ondervraging van kenners der Philippijnen door de senaatscommissie (van 14 December 1914 tot 11 Januari 1915) en het daarna uitgebrachte commissieverslag van 2 Februari 1915 volgde geen eerdere bespreking van het ontwerp dan op 3 Maart 1915 (den dag vóór het uiteengaan van het congres), waarbij het van de agenda werd afgevoerd. Dientengevolge verviel het tweede ontwerp op 4 Maart 1915. Van vele zijden is de senaat deswege beticht van obstructie (filibustering tactics).

Echter diende op 7 December 1915 , tijdens het $64^{\text {ste }}$ congres derhalve (1915-1917), de democratische senator Hitchcock (Nebraska), voorzitter van de senaatscommissie voor Philippijnsche zaken, bij den senaat een wetsontwerp van 33 artikelen in, nagenoeg gelijkluidend met den in October 1914 door het huis gevoteerden tekst in 29 artikelen van het tweede ontwerp-Jones, en in de wandeling aangeduid als the Philippine bill. Na een gunstig commissieverslag van 17 December 1915 en een gewijzigd ontwerp van denzelfden dag - hetwelk de beweegreden veranderde en het jaartal 1915 in het artikel over de eerste verkiezingen op den nieuwen voet (artikel 21) verving door 1916 had de behandeling in openbaar comité-generaal (Senate Committee of the Whole on the state of the Union, onder den gewonen senaatspresident, zijnde den vicepresident der Vereenigde Staten) plaats van 6 Januari 1916 tot 3 Februari 1916 en die in den senaat zelf op 3 en 4 Februari 1916. Tijdens de behandeling in comité-generaal werden, naast een reeks door de senaatscommissie zelf voorgestelde amendementen van redactionneelen aard, twee verrassende wijzigingen aangenomen. Vooreerst werd op 18 Januari 1916 met 35 tegen 23 stemmen aanvaard een amendement van senator Gronna (North Dakota), hetwelk in artikel 3 achter het polygamieverbod een verbod van sterke dranken inlaschte, echter niet, dan nadat eerst aan dit amendement-Gronna met 32 tegen 26 stemmen een 
moordend subamendement-Hitchcock was toegebracht, hetwelk alle inlandsche sterke dranken, ook de meest bedwelmende, met zooveel woorden aan dit drankverbod onttrok. In de tweede en veel belangrijker plaats werd, na een veertiendaagsche discussie en ondanks het verzet van den wetsvoorsteller-Hitchcock zelf, op 2 Februari 1916 in dit comité-generaal een amendement aangenomen van senator Clarke (Arkansas), hetwelk, ter vervanging van onafhankelijkheidsbeloften in de beweegreden alleen, de wet zelf in een slotartikel 34 deed bepalen, dat de Amerikaansche heerschappij over de Philippijnen zou eindigen op een door den president der Vereenigde Staten te bepalen dag tusschen twee en vier jaar na de bekrachtiging van de wet; hetgeen derhalve zou geleid hebben tot vrijverklaring tusschen Augustus 1918 en Augustus 1920, of nog een klein jaar vroeger dan het eerste ontwerp-Jones van 1912 had gewild, waar van 4 Juli 1921 als vrijheidsdag was gesproken. Wel is waar liet de tekst zelf van het amendement-Clarke nog ruimte voor verdaging van den begindag der onafhankelijkheid, doch men begreep wel, dat, indien eenmaal de wet zulk een begindag had aangegeven, verdaging practisch zou afstuiten op de Filipino's; aan deze verdagingsbevoegdheid is dan ook bij de debatten geen aandacht gegeven. Nadat een aantal subamendementen en subsubamendementen verworpen waren, en alleen een subamendement-Kenyon was aangenomen (op 2 Februari 1916, met 53 tegen 31 stemmen), strekkende om internationale waarborging van de onaf hankelijkheid der Philippijnen uit het amendement te schrappen, staakten over het amendement-Clarke zelf op 2 Februari 1916 in comité-generaal de stemmen (41 tegen 41), waarna de stem van den voorzitter, den democratischen vicepresident der Vereenigde Staten, den doorslag gaf ten gunste van het amendement. Hangende deze discussie had op 25 Januari 1916 de Philippijnsche tweede kamer te Manila eenparig een resolutie gevoteerd ten gunste van het amendement-Clarke. Toen na afhandeling in comité-generaal het ontwerp-Hitchcock met zijn amendementen aan den senaat zelf werd voorgelegd, stelde op 4 Februari 1916 senator Clarke op zijn eigen amendement een klein subamendement voor (hieronder aangegeven door spatieering); dit subamendement werd aanvaard, het gewijzigde amendement-Clarke (artikel 34) gevoteerd met 48 tegen 27 stemmen, en het geheele ontwerp zelf met 52 stemmen (alle democratische, plus een paar republikeinsche) 
tegen 24 (republikeinsche) stemmen. De redactie van het amendement was nu geworden als volgt:

Sec. 34. The President is hereby authorized and directed to withdraw and surrender all right of possession, supervision, jurisdiction, control, or sovereignty now existing and exercised by the United States in and over the territory and people of the Philippines, and he shall on behalf of the United States fully recognize the independence of the said Philippines as a separate and self-governing nation and acknowledge the authority and control over the same of the government instituted by the people thereof, and full power to take the several steps necessary to institute such government is hereby conferred upon the said Philippines acting by and through governmental agencies created by this act. This transfer of possession, sovereignty, and governmental control shall be completed and become absolute not less than two years nor more than four years from the date of the approval of this act, under the terms and in the manner hereinafter prescribed: Provided, That if the President, prior to the expiration of the said period of four years, shall find that the condition of the internal or external affairs of said Philippines in respect to the stability or efficiency of the proposed government thereof is such as to warrant him in so doing, he is hereby further authorized, by proclamation duly made and published, to extend the said time to and including the date of the final adjournment of the session of Congress which shall convene next after the date of the expiration of the said period of four years, and thus afford the Congress an opportunity in its discretion to further consider the situation in the said Philippines; but any such extension of time by the President shall not otherwise suspend or nullify the operative force of this act, unless the Congress shall hereafter so direct. For the purpose of a complete and prompt compliance with this direction, the President is hereby invested with full power and authority to make such orders and regulations and to enter into such negotiations with the authorities of said Philippines or others as may be necessary to finally settle and adjust all property rights and other relations as between the United States and the said Philippines, and to cause to be acknowledged, respected, and safeguarded all of the personal and property rights of citizens or corporations of the United States and of other countries resident or engaged in business in said Philippines or having property interests therein. In any such settlement or adjustment so made in respect to the rights and property of the United States as against the said Philippines 
the President may reserve or acquire such lands and rights and privileges appurtenant thereto as may, in his judgment, be required by the United States for naval bases and coaling stations within the territory of said Philippines.

En hier begint nu de zaak voor niet-Amerikaansche lezers verward te worden. Het senaatsontwerp-Hitchcock met de amendementen-Gronna en -Clarke kwam bij het huis van afgevaardigden in op 8 Februari 1916. Het commissieverslag van 6 April 1916 (meerderheid, vóór) en 12 April 1916 (minderheid, tegen) sloeg geen bepaalde wijzigingen voor. De behandeling in openbaar comité-generaal van het huis en die in het huis zelf besloegen maar één enkelen dag, 1 Mei 1916. Op dien eenen dag nu werd, vooreerst, in comité-generaal door een amendement- of motieTowner het nieuwe artikel 34, zijnde het senaatsamendementClarke, weer uit het wetsontwerp gelicht met 193 tegen 151 stemmen (na de algemeene beschouwingen was men terstond met artikel 34 begonnen), terwijl twee voorstellen van Jones om andere termijnbepalingen in artikel 34 te krijgen («tusschen twee en zes jaar»; "tusschen vier en acht jaar») met diergelijke meerderheden werden verworpen. Vervolgens - en hier komt het opvallende - stelde Jones voor a) om artikel 1 van het aanhangige senaatsontwerp te vervangen door de artikelen $1-29$ van zijn eigen, in October 1914 aangenomen, tweede ontwerp, en b) om de resteerende artikelen 2-33 van het senaatsontwerp te schrappen. Beide voorstellen, reeds geopperd in het minderheidsrapport van 12 April 1916, werden grif aanvaard; alleen bleek er eenige - niet recht opgeloste — onzekerheid over de louter formeele vraag, of artikel 1 van het senaatsontwerp was blijven bestaan, dan of het vervangen was door het daarmee volkomen gelijkluidende artikel 1 van October 1914. Nadat daarna ook nog - na eenig dispuut over de kwestie, of de considerans in comité-generaal mocht worden vastgesteld, dan aan het huis zelf moest worden overgelaten - de beweegreden van het senaatsontwerp door die van het tweede ontwerp-Jones was vervangen, en het geheele aldus vervormde ontwerp was gevoteerd in comité-generaal met 199 tegen 152 stemmen, kwam de zaak in het huis zelf aan de orde, waar de schrapping van artikel 34 werd bekrachtigd met 213 tegen 165 stemmen, en de vervanging van de artikelen $1-33$ of $2-33$ met 251 tegen 17 stemmen, terwijl de nieuwe beweegreden werd goedgekeurd zonder stemming. 
Naar den vorm had men derhalve nu een zwaar geamendeerd senaatsontwerp-Hitchcock; naar den inhoud had men het in October 1914 gevoteerde ontwerp-Jones terug, zonder andere afwijking - naar het schijnt - dan in een paar data.

Zoo zou nu een conferentie tusschen beide huizen van het congres wel onvermijdelijk worden. Terstond na de eindstemming dan ook werd met het oog daarop besloten (met 203 tegen 156 stemmen) den afgevaardigden van het huis naar deze conferentie op te dragen, in geen geval voor het verleenen van onafhankelijkheid aan de Philippijnen een termijnbepaling te aanvaarden.

$\mathrm{Nu}$ was het woord weer aan den senaat. Aldaar kwam op 8 Mei 1916 allereerst de vraag ter sprake, of men wellicht (gelijk Hitchcock wilde) het terugontvangen wetsontwerp maar zou aanvaarden met de volledige wijziging, door het huis daarin aangebracht. Op 29 Mei 1916 evenwel besloot de senaat in ontkennenden zin; op 18 Juli 1916 bewilligde de senaat in een conferentie, hoewel de door het huis aan zijn afgevaardigden opgelegde instructie niet bijster beleefd gevonden werd.

Van toen af schijnt de zaak te hebben geloopen op rolletjes. Een conferentierapport van 7 Augustus 1916 beval aan, dat de senaat zijn bezwaren tegen de wijzigingen van het huis zou opgeven, mits een viertal werkelijke en voorts enkele redactionneele wijzigingen werden opgenomen. Een rapport van 15 Augustus 1916 van het huis gaf den voorgestelden nieuwen tekst der artikelen 1-31 (want er waren twee artikelen bijgekomen), zonder de beweegreden van het ontwerp. Op 16 Augustus 1916 aanvaardde de senaat de conferentievoorstellen met 37 tegen 22 stemmen, op 18 Augustus aanvaardde het huis ze. Vóór en op 22 Augustus werd het ontwerp achtereenvolgens geteekend door de voorzitters van beide huizen, en op 29 Augustus 1916 werd het door den president bekrachtigd. De vier werkelijke wijzigingen; door de conferentie voorgesteld, hadden a) het kiezerscorps voor de eerstkomende verkiezing onveranderd gehouden (artikel 15. lid 1), b) Amerikaansche burgers stemgerechtigd gemaakt (artikel 15 lid 2) naast burgers der Philippijnen, c) een vasten ondergouverneur (luitenant-gouverneur-generaal, zouden wij zeggen) ingesteld met leidende bevoegdheid in zake volksopvoeding en volksgezondheid (artikel 23) - deze twee vitale belangen zijn daardoor voorshands voorbehouden aan een 
Amerikaansch dignitaris - , en d) een auditor (vergelijkbaar met onze rekenkamers), die reeds voorkwam in het eerste ontwerpHitchcock van 7 December 1915, ingevoegd in twee nieuwe artikelen (artikelen 24 en 25).

Het somtijds betwijfeld idealisme van den Amerikaanschen geest komt in de debatten over dit Philippijnsche regeeringsreglement van 1916 weer sprekend uit in het feit, dat, zoowel in het huis als in den senaat, betoogen tot aanwijzing van zakelijke bezwaren tegen spoedige vrijmaking herhaaldelijk metoprechte waardeering, doch betoogen ten gunste van vrijmaking telkens met echte geestdrift zijn ontvangen. Vergelijking met den Amerikaanschen vrijheidsoorlog, aanhaling van beroemde vrijheidswoorden van Jefferson of Lincoln miste nimmer haar enthousiasmeerende werking. De handelingen van het congres (Congressional Record) namelijk geven instemming en afkeuring weer.

Het opschrift der wet - "To declare the purpose of the people of the United States as to the future political status of the people of the Philippine Islands, and to provide a more autonomous government for those islands - - is sinds het ontwerp van 1914 onveranderd gebleven. Hoewel de juistheid van dit opschrift ( "title») het soms geducht heeft moeten ontgelden tijdens de beraadslaging, blijkt uit de handelingen van het congres nergens, dat en hoe het gevoteerd is geworden.

II.

\section{De artikelen.}

De aandacht, aan de artikelen zelf der wet gegeven, schijnt al zeer onregelmatig verdeeld geweest. De commissieverslagen van April 1912 (huis), Augustus 1914 (huis), December 1915 (senaat) en April 1916 (huis) zijn over de artikelen uitermate laconisch; dat van Februari 1915 (senaat) doet concrete voorstellen, doch zonder redacties aan te geven. De discussies van September en October 1914 in het huis gaven aan de artikelen de noodige zorg; de senaatsdiscussies van Januari 1916 zoogoed als geen (Kenyon op 10 en 18 Januari was de uitzondering), evenals - uiteraard - de korte discussie van Mei 1916 in het huis. Het conferentierapport van Augustus 1916 gaat op eens weer vrij ver in de zorg voor een goeden inhoud der artikelen. Maar nergens vindt men de gevoteerde teksten van amendementen 
en artikelen duidelijk afgedrukt, en nergens ook vindt men de moeite genomen om de afwisselende redacties van vroegere en latere voorstellen naast elkaar te drukken op een wijze, die de verschillen doet in het oog springen; zoodat het uiterst tijdroovend is om b.v. de verschillen tusschen het ingediende en het gevoteerde tweede ontwerp-Jones en die tusschen het gevoteerde ontwerpJones en het senaatsontwerp-Hitchcock te leeren kennen, of die tusschen het tweede ontwerp-Jones en den gesubstitueerden tekst van Mei 1916. Ook van particuliere zijde schijnt dit nuttige, maar nu juist niet amusante geduldwerkje niet verricht. Op 29 Mei 1916 constateerde senator Lippitt (Rhode Island), dat tusschen het senaatsontwerp-Hitchcock en het tweede ontwerpJones (of, anders gezegd, het sterk geamendeerde senaatsontwerp) een twintigtal verschillen bestonden, waaronder sommige van vitaal belang; maar men vindt ze nergens gespecificeerd.

Hier moet vooreerst iets gezegd over twee ontbrekende artikelen.

Een drankverbodartikel, in October 1914 vergeefs voorgesteld in het huis, in Januari 1916 door den senaat in artikel 3 ingeschoven, kwam in Mei 1916 vanzelf te vervallen door het herstellen van de redactie van 1914, waaraan zulk een verbod vreemd was. De droefheid van senator Gronna over dit wegvallen van zijn voedsterling werd comisch, toen het volstrekt onmogelijk bleek dit lid der hooge vergadering aan het verstand te brengen, op welke wijze zijn invoeging dan toch wel geëclipseerd was.

Ten andere ontbreekt een wetsvoorschrift over neutralisatie (duurzame neutraliteit) der Philippijnen of over een poging om tot neutralisatie of internationale waarborging te geraken. In Februari 1908 reeds had senator Stone (Misssouri) een gemeenschappelijke resolutie te dier zake voorgesteld; in Maart 1912 had Jones in het huis een soortgelijk voorstel gedaan, waarover in Mei 1912 verslag was uitgebracht, doch dat verder was blijven rusten; in 1914 had senator Overman (North Carolina), in 1915 senator Shafroth (Colorado) het voorstel herhaald. Op 13 Januari 1916 in den senaat diende senator McCumber (North Dakota) een amendement van deze strekking in, hetwelk geen succes had; op 1 Mei 1916, bij de hernieuwde behandeling in het huis, diende het kamerlid Sabath zulk een amendement in, doch alleen om het na één minuut weer terug te nemen. Bij deze reeks van pogingen is het gebleven. 
Andere amendementen echter zijn geslaagd.

In artikel 3 der wet is in October 1914 bij amendement een regel gesteld voor onteigening en wellicht andersoortige ontneming van eigendom: "Private property shall not be taken for public use without just compensation». Voor het speciale geval van werken van openbaar nut bepaalt het tegenwoordige artikel 28 (zooals geamendeerd in October 1914) dit zelfde bovendien voor schade, toegebracht aan bijzonderen eigendom ( no private property shall be damaged or taken for any purpose under this section without just compensation ", en uit dat artikel 28 werd te dier gelegenheid de toevoeging van het «hetzij betaald of verzekerd zijn» van de schadeloosstelling ("without just compensation paid or tendered therefor») als overtollig geschrapt.

In artikel 3 is in October 1914 het verbod gebracht van veelvrouwendom. Op 18 Januari 1916 is in den senaat de redactie aldus verbeterd, dat het verbod kennelijk alleen op de toekomst slaat ("hereafter»). Het conferentierapport van Augustus 1916 heeft nog een zinsnede toegevoegd om ontduiking te keeren.

De artikelen 13-16 over het Philippijnsche parlement hebben hun definitieve redactie pas gekregen in 1916. Het tweedè ontwerp-Jones had zich een samenkomen van die vernieuwde vertegenwoordiging voorgesteld in het jaar 1915.

In artikel 18 is in October 1914 onder meer ingelascht de zoogenaamde onschendbaarheid van parlementsleden: "and for any speech or debate in either house they shall not be questioned in any other place».

Ook artikel 20 over de koloniale hulpafgevaardigden te Washington heeft zijn definitieve redactie (zitting voor drie jaar, en verkiezing niet door de kiezers in de Philippijnen, maar — gelijk vóór 1916 - door het parlement te Manila) eerst gekregen door het conferentierapport van Augustus 1916.

De artikelen 24 en 25 over den auditor (vergelijkbaar met onze rekenkamers) dateeren van het eerste ontwerp-Hitchcock (December 1915) en zijn hersteld door het conferentierapport van Augustus 1916.

Artikel 27 zou volgens het tweede ontwerp-Jones het hooggerechtshof te Washington bevoegd hebben verklaard de arresten van het hooggerechtshof te Manila slechts dan te herzien, indien het staatsrecht der Vereenigde Staten of eenig eigen recht der Vereenigde Staten betrokken was bij de uitspraak. In October 
1914 is de redactie van het regeeringsreglement van 1902 te dezen hersteld door toevoeging van de woorden, dat het hooggerechtshof te Washington mede bevoegd zal zijn in civiele zaken, waarbij de waarde in geschil of de waarde van onroerend goed in geschil meer bedraagt dan 25.000 dollar. Het hooggerechtshof te Manila is dus nog niet ontvoogd, gelijk dat te Weltevreden.

Als sprekend bewijs, dat men aan de redactie der artikelen waarvan hier alleen de voornaamste punten behoefden te worden vermeld, zonder streven naar volledigheid - wel wat meer aandacht had kunnen geven, moge volstaan, dat uit artikel 1 van het eerste ontwerp-Jones in alle volgende ontwerpen en ten slotte in artikel 1 der wet zelf is overgegaan de vermelding van een op 11 April 1899 tusschen Amerika en Spanje gesloten vredesverdrag, - terwijl niet alleen zulk een verdrag niet bestaat (11 April 1899 is de dag der uitwisseling van de ratificaties geweest), maar het later, bij het tweede ontwerp-Jones, ingelaschte artikel 2 dezer zelfde wet den juisten datum (10 December 1898) bevat. Hoewel de fout op 2 October 1914 opzettelijk ter sprake werd gebracht, is zij nochtans blijven staan. De klacht van senator Lippitt op 8 Mei 1916, dat het publiek niet genoeg eerbied heeft voor het in stilte verrichte werk eener goede redactie, stelt de voorbereiding van dit regeeringsreglément dus in sommig opzicht te fraai voor.

Op het gewichtig stuk der onafhankelijkverklaring is het verloop der redacties geweest als volgt. Het eerste ontwerpJones van 1912 kende, gelijk hiervoren vermeld, de onafhankelijkheid met zooveel woorden toe, te rekenen van 4 Juli 1921 . Het tweede ontwerp-Jones van 1914 beloofde onafhankelijkheid, zoodra een stevig bewind (a stable government) kan worden ingericht in de Philippijnen. Het in October 1914 gevoteerde ontwerp en evenzoo het senaatsontwerp van 7 December 1915 bepaalde - geheel overeenkomstig de herhaalde beloften van presidenten en landvoogden —, dat onaf hankelijkheid zou intreden, zoodra, naar het oordeel der Vereenigde Staten, het volk der Philippijnen voor onafhankelijkheid rijp zou zijn gebleken ( grant when, in the judgment of the United States, the people of the Philippine Islands shall have shown themselves to be fitted therefor $»)$. In de gewijzigde senaatsredactie van tien dagen later daarentegen (17 December 1915) werd als criterium aan- 
genomen, of het verleenen van onafhankelijkheid al dan niet in het duurzaam belang der bevolking zou zijn ("to grant when, in the judgment of the United States, it will be to the permanent interest of the people of the Philippine Islands»), hetgeen dus mogelijk maakte haar te onthouden, ook al zou de bevolking voor zelf bewind rijp wezen. Volgens het amendement-Clarke zou onaf hankelijkverklaring (behoudens het onaannemelijke geval van verdaging) verplicht zijn geweest tusschen 1918 en 1920; als curiosum mag hier niet onvermeld blijven, dat op 18 Augustus 1916 in het huis tegen het amendement-Clarke een beroep is gedaan op den heer Colijn. Het bekrachtigde regeeringsreglement van 1916, eindelijk, bepaalt weer precies wat het tweede ontwerpJones aanvankelijk voorschreef: "whereas it is, as it has always been, the purpose of the people of the United States to withdraw their sovereignty over the Philippine Islands and to recognize their independence as soon as a stable government can be established therein». Onder de talrijke te dezer zake geopperde ideeën verdient vermelding dat van senator Shafroth (Colorado) op 7 Januari 1916: dat wellicht de overgang tusschen oud en nieuw het best te treffen ware door als laatsten landvoogd onder Amerikaansche heerschappij een Filipino te benoemen.

Ten slotte trekt het de aandacht, dat het regeeringsreglement van 1916 zijn voorganger van 1902 niet heeft ingetrokken, doch integendeel bepaalt (artikel 31), dat alle wetten of wettelijke voorschriften, welke met het regeeringsreglement van 1916 niet strijdig zijn, worden gehandhaafd. Practijk, rechtspraak en wetenschap zullen dus hebben uit te maken, wat van de oude wet van 1902 nog geldt. Na het in September 1916 voltooide boek over Philippijnsche staatsinstellingen van den tegenwoordigen raadsheer in het hooggerechtshof der Philippijnen G. A. Malcolm (The government of the Philippine Islands, Rochester, N. Y., 1916; 794 blz.) schijnt in druk niets samenvattends over Philippijnsch staatsrecht te zijn verschenen; het in 1919 uitgekomen werkje van dezen zelfden Malcolm en M. M. Kalaw (den op blz. 450 reeds genoemden jongen Filipino, nu hoogleeraar te Manila) over "Philippine civics» (Appleton \& Co., New York, 1919; 183 blz.) is te elementair om in dit verband te worden meegeteld.

Toen in Juli 1914 de tweede Jones bill was ingediend, werd de tekst afgedrukt in schier alle bladen der Philippijnen en in de drie voornaamste inheemsche talen (Visaya, Tagalog en Iloco); 
vóór het eind van Augustus 1914 hadden al drie provinciale besturen en veertig gemeentebesturen in de Philippijnen hun instemming betuigd, evenals het bestuur der nationalistische partij aldaar (de partij der meerderheid). Toen in Februari 1916 de Philippine bill, het wetsontwerp van den senaat, met het amendementClarke nopens een over twee à vier jaar te verleenen onaf hankelijkheid was aangenomen, moet het te Manila verschenen zijn in brochurevorm in de voornaamste inheemsche taal van het eiland Luzón, het Tagalog (gesproken door anderhalf millioen van de bijna tien millioen inwoners der Philippijnen); een congreslid deelde op 1 Mei 1916 mede, dat een inlandsche boekwinkel in korten tijd van deze brochure meer dan 100.000 exemplaren had verkocht. Anderzijds geven een aantal Philippijnsche persstemmen, door den deskundigen en welgezinden J. A. Robertson bijeengebracht in The Journal of Race Development van April 1916, den indruk, dat het vooruitzicht volle onafhankelijkheid te zullen krijgen op zóó korten termijn bij vele toongevende Filipino's destijds een gevoel van beklemming wekte.

Dat, ondanks den oorlog, de sinds 1916 verloopen jaren voor de economische ontwikkeling der Philippijnen in menig opzicht gunstig zijn geweest, heeft voor het regeeringsreglement van 1916 een goede atmosfeer geschapen, hoewel de tekst van dat regeeringsreglement aan dien toestand wellicht part noch deel heeft gehad. Volgens alle verklaringen van den huidigen gouverneur-generaal (F. B. Harrison, democraat, sinds 1913) is de met het regeeringsreglement opgedane ervaring hoogst bevredigend.

III.

\section{De tekst der wet.}

\section{[Public-No. 240-64th Congress.]}

[S. 381.]

An Act To declare the purpose of the people of the United States as to the future political status of the people of the Philippine Islands, and to provide a more autonomous government for those islands.

Whereas it was never the intention of the people of the United States in the incipiency of the War with Spain to make it a war of conquest or for territorial aggrandizement; and 
Whereas it is, as it has always been, the purpose of the people of the United States to withdraw thier sovereignty over the Philippine Islands and to recognize their independence as soon as a stable government can be established therein; and

Whereas for the speedy accomplishment of such purpose it is desirable to place in the hands of the people of the Philippines as large a control of their domestic affairs as can be given them without, in the meantime, impairing the exercise of the rights of sovereignty by the people of the United States, in order that, by the use and exercise of popular franchise and governmental powers, they may be the better prepared to fully assume the responsibilities and enjoy all the privileges of complete independence: Therefore Be it enacted by the Senate and House of Representatives of the United States of America in Congress assembled, That the provisions of this Act and the name "The Philippines» as used in this Act shall apply to and include the Philippine Islands ceded to the United States Government by the treaty of peace concluded between the United States and Spain on the eleventh day of April, eighteen hundred and ninety-nine, the boundaries of which are set forth in Article III of said treaty, together with those islands embraced in the treaty between Spain and the United States concluded at Washington on the seventh day of November, nineteen hundred.

SEC. 2. That all inhabitants of the Philippine Islands who were Spanish subjects on the eleventh day of April, eighteen hundred and ninety-nine, and then resided in said islands, and their children born subsequent thereto, shall be deemed and held to be citizens of the Philippine Islands, except such as shall have elected to preserve their allegiance to the Crown of Spain in accordance with the provisions of the treaty of peace between the United States and Spain, signed at Paris December tenth, eighteen hundred and ninety-eight, and except such others as have since become citizens of some other country: Provided, That the Philippine Legislature, herein provided for, is hereby authorized to provide by law for the acquisition of Philippine citizenship by those natives of the Philippine Islands who do not come within the foregoing provisions, the natives of the insular possessions of the United States, and such other persons residing in the Philippine Islands who are citizens of 
the United States, or who could become citizens of the United States under the laws of the United States if residing therein.

SEC. 3. That no law shall be enacted in said islands which shall deprive any person of life, liberty, or property without due process of law, or deny to any person therein the equal protection of the laws. Private property shall not be taken for public use without just compensation.

That in all criminal prosecutions the accused shall enjoy the right to be heard by himself and counsel, to demand the nature and cause of the accusation against him, to have a speedy and public trial, to meet the witnesses face to face, and to have compulsory process to compel the attendance of witnesses in his behalf.

That no person shall be held to answer for a criminal offense without due process of law; and no person for the same offense shall be twice put in jeopardy of punishment, nor shall be compelled in any criminal case to be a witness against himself.

That all persons shall before conviction be bailable by sufficient sureties, except for capital offenses.

That no law impairing the obligation of contracts shall be enacted.

That no person shall be imprisoned for debt.

That the privilege of the writ of habeas corpus shall not be suspended, unless when in cases of rebellion, insurrection, or invasion the public safety may require it, in either of which events the same may be suspended by the President, or by the Governor General, wherever during such period the necessity for such suspension shall exist.

That no ex post facto law or bill of attainder shall be enacted nor shall the law of primogeniture ever be in force in the Philippines.

That no law granting a title of nobility shall be enacted, and no person holding any office of profit or trust in said islands shall, without the consent of the Congress of the United States, accept any present, emolument, office, or title of any kind whatever from any king, queen, prince, or foreign State.

That excessive bail shall not be required, nor excessive fines imposed, nor cruel and unusual punishment inflicted. Dl. 75 
That the right to be secure against unreasonable searches and seizures shall not be violated.

That slavery shall not exist in said islands; nor shall involuntary servitude exist therein except as a punishment for crime whereof the party shall have been duly convicted.

That no law shall be passed abridging the freedom of speech or of the press, or the right of the people peaceably to assemble and petition the Government for redress of grievances.

That no law shall be made respecting an establishment of religion or prohibiting the free exercise thereof, and that the free exercise and enjoyment of religious profession and worship, without discrimination or preference, shall forever be allowed; and no religious test shall be required for the exercise of civil or political rigths. No public money or property shall ever be appropriated, applied, donated, or used, directly or indirectly, for the use, benefit, or support of any sect, church denomination, sectarian institution, or system of religion, or for the use, benefit, or support of any priest, preacher, minister, or other religious teacher or dignitary as such. Contracting of polygamous or plural marriages hereafter is prohibited. That no law shall be construed to permit polygamous or plural marriages.

That no money shall be paid out of the treasury except in pursuance of an appropriation by law.

That the rule of taxation in said islands shall be uniform.

That no bill which may be enacted into law shall embrace more than one subject, and that subject shall be expressed in the title of the bill.

That no warrant shall issue but upon probable cause, supported by oath or affirmation, and particularly describing the place to be searched and the person or things to be seized.

That all money collected on any tax levied or assessed for a special purpose shall be treated as a special fund in the treasury and paid out for such purpose only.

SEC. 4. That all expenses that may be incurred on account of the Government of the Philippines for salaries of officials and the conduct of their offices and departments, and all expenses and obligations contracted for the internal improvement or development of the islands, not, however, including defenses, barracks, and other works undertaken by the United States, shall, except 
as otherwise specifically provided by the Congress, be paid by the Government of the Philippines.

SEC. 5. That the statutory laws of the United States hereafter enacted shall not apply to the Philippine Islands, except when they specifically so provide, or it is so provided in this Act.

SEC. 6. That the laws now in force in the Philippines shall continue in force and effect, except as altered, amended, or modified herein, until altered, amended, or repealed by the legislative authority herein provided or by Act of Congress of the United States.

SEC. 7. That the legislative authority herein provided shall have power, when not inconsistent with this Act, by due enactment to amend, alter, modify, or repeal any law, civil or criminal, continued in force by this Act as it may from time to time see fit.

This power shall specifically extend with the limitation herein provided as to the tariff to all laws relating to revenue and taxation in effect in the Philippines.

SEC. 8. That general legislative power, except as otherwise herein provided, is hereby granted to the Philippine Legislature, authorized hy this Act.

SEC. 9. That all the property and rights which may have been acquired in the Philippine Islands by the United States under the treaty of peace with Spain, signed December tenth, eighteen hundred and ninety-eight, except such land or other property as has been or shall be designated by the President of the United States for military and other reservations of the Government of the United States, and all lands which may have been subsequently acquired by the government of the Philippine Islands by purchase under the provisions of sections sixty-three and sixty-four of the Act of Congress approved July first, nineteen hundred and two, except such as may have heretofore been sold and disposed of in accordance with the provisions of said Act of Congress, are hereby placed under the control of the government of said islands to be administered or disposed of for the benefit of the inhabitants thereof, and the Philippine Legislature shall have power to legislate with respect to all such matters as it may deem advisable; but acts of the Philippine Legislature with reference to land of the public domain, timber, and mining, hereafter enacted, shall not have the force of law until approved 
by the President of the United States: Provided, That upon the approval of such an act by the Governor General, it shall be by him forthwith transmitted to the President of the United States, and he shall approve or dissapprove the same within six months from and after its enactment and submission for his approval, and if not disapproved within such time it shall become a law the same as if it had been specifically approved: Provided further, That where lands in the Philippine Islands have been or may be reserved for any public purpose of the United States, and, being no longer required for the purpose for which reserved, have been or may be, by order of the President, placed under the control of the government of said islands to be administered for the benefit of the inhabitants thereof, the order of the President shall be regarded as effectual to give the government of said islands full control and power to administer and dispose of such lands for the benefit of the inhabitants of said islands.

SEC. 10. That while this Act provides that the Philippine government shall have the authority to enact a tariff law the trade relations between the islands and the United States shall continue to be governed exclusively by laws of the Congress of the United States: Provided, That tariff acts or acts amendatory to the tariff of the Philippine Islands shall not become law until they shall receive the approval of the President of the United States, nor shall any act of the Philippine Legislature affecting immigration or the currency or coinage laws of the Philippines become a law until it has been approved by the President of the United States: Provided further, That the President shall approve or disapprove any act mentioned in the foregoing proviso within six months from and after its enactment and submission for his approval, and if not disapproved within such time it shall become a law the same as if it had been specifically approved.

SEC. 11. That no export duties shall be levied or collected on exports from the Philippine Islands, but taxes and assessments on property and license fees for franchises, and privileges, and internal taxes, direct or indirect, may be imposed for the purposes of the Philippine government and the provincial and municipal governthents thereof, respectively, as may be provided and defined by acts of the Philippine Legislature, and, where necessary to 
anticipate taxes and revenues, bonds and other obligations may be issued by the Philippine government or any provincial or municipal government therein, as may be provided by law and to protect the public credit: Provided, however, That the entire indebtedness of the Philippine government created by the authority conferred herein shall not exceed at any one time the sum of $\$ 15,000,000$, exclusive of those obligations known as friar land bonds, nor that of any Province or municipality a sum in excess of seven per centum of the aggregate tax valuation of its property at any one time.

SEC. 12. That general legislative powers in the Philippines, except as herein otherwise provided, shall be vested in a legislature which shall consist of two houses, one the senate and the ather the house of representatives, and the two houses shall be designated "The Philippine Legislature»: Provided, That until the Philippine Legislature as herein provided shall have been organized the existing Philippine Legislature shall have all legislative authority herein granted to the government of the Philippine Islands, except such as may now be within the exclusive jurisdiction of the Philippine Commission, which is so continued until the organization of the legislature herein provided for the Philippines. When the Philippine Legislature shall have been organized, the exclusive legislative jurisdiction and authority exercised by the Philippine Commission shall thereafter be exercised by the Philippine Legislature.

SEC. 13. That the members of the senate of the Philippines, except as herein provided, shall be elected for terms of six and three years, as hereinafter provided, by: the qualified electors of the Philippines. Each of the senatorial districts defined as hereinafter provided shall have the right to elect two senators. No person shall be an elective member of the senate of the Philippines who is not a qualified elector and over thirty years of age, and who is not able to read and write either the Spanish or English language, and who has not been a resident of the Philippines for at least two consecutive years and an actual resident of the senatorial district from which chosen for a period of at least one year immediately prior to his election,

SEC. 14. That the members of the house of representatives shall, except as herein provided, be elected triennially by the qualified electors of the Philippines. Each of the representative 
districts hereinafter provided for shall have the right to elect one representative. No person shall be an elective member of the house of representatives who is not a qualified elector and over twenty-five years of age, and who is not able to read and write either the Spanish or English language, and who has not been an actual resident of the district from which elected for at least one year immediately prior to his election: Provided, That the members of the present assembly elected on the first Tuesday in June, nineteen hundred and sixteen, shall be the members of the house of representatives from their respective districts for the term expiring in nineteen hundred and nineteen.

SEc. 15. That at the first election held pursuant to this act, the qualified electors shall be those having the qualifications of voters under the present law; thereafter and until otherwise provided by the Philippine Legislature herein provided for the qualifications of voters for senators and representatives in the Philippines and all officers elected by the people shall be as follows:

Every male person who is not a citizen or subject of a foreign power twenty-one years of age or over (except insane and feeble-minded persons and those convicted in a court of competent jurisdiction of an infamous offense since the thirteenth day of August, eighteen hundred and ninety-eight), who shall have been a resident of the Philippines for one year and of the municipality in which he shall offer to vote for six months next preceding the day of voting, and who is comprised within one of the following classes:

(a) Those who under existing law are legal voters and have exercised the right of suffrage.

(b) Those who own real property to the value of 500 pesos, or who annually pay 30 pesos or more of the established taxes.

(c) Those who are able to read and write either Spanish, English, or a native language.

SEC. 16. That the Philippine Islands shall be divided into twelve senate districts, as follows:

First district: Batanes, Cagayan, Isabela, Ilocos Norte, and Ilocos Sur.

Second district: La Union, Pangasinan, and Zambales.

Third district: Tarlac, Nueva Ecija, Pampanga, and Bulacan.

Fourth district: Bataan, Rizal, Manila, and Laguna. 
Fifth district: Batangas, Mindoro, Tayabas, and Cavite. Sixth district: Sorsogon, Albay, and Ambos Camarines. Seventh district: Iloilo and Capiz.

Eighth district: Negros Occidental, Negros Oriental, Antique, and Palawan.

Ninth district: Leyte and Samar.

Tenth district: Cebu.

Eleventh district: Surigao, Misamis, and Bohol.

Twelfth district: The Mountain Province, Baguio, Nueva Vizcaya, and the Department of Mindanao and Sulu.

The representative districts shall be the eighty-one now provided by law, and three in the Mountain Province, one in Nueva Vizcaya, and five in the Department of Mindanao and Sulu.

The first election under the provisions of this Act shall be held on the first Tuesday of October, nineteen hundred and sixteen, unless the Governor General in his discretion shall fix another date not earlier than thirty nor later than sixty days after the passage of this Act: Provided, That the Governor General's proclamation shall be published at least thirty days prior to the date fixed for the election, and there shall be chosen at such election one senator from each senate district for a term of three years and one for six years. Thereafter one senator from each district shall be elected from each senate district for a term of six years: Provided, That the Governor General of the Philippine Islands shall appoint, without the consent of the senate and without restriction as to residence, senators and representatives who will, in his opinion, best represent the senate district and those reprensentative districts which may be included in the territory not now represented in the Philippine Assembly: Provided further, That thereafter elections shall be held only on such days and under such regulations as to ballots, voting, and qualifications of electors as may be prescribed by the Philippine Legislature, to which is hereby given authority to redistrict the Philippine Islands and modify, amend, or repeal any provision of this section, except such as refer to appointive senators and repesentatives.

SEC. 17. That the terms of office of elective senators and representatives shall be six and three years, respectively, and shall begin on the date of their election. In case of vacancy among the elective members of the senate or in the house of representatives, special 
elections may be held in the districts wherein such vacancy occurred under such regulations as may be prescribed by law, but senators or representatives elected in such cases shall hold office only for the unexpired'portion of the term wherein the vacancy occurred. Senators and representatives appointed by the Governor General shall hold office until removed by the Governor General.

SEC. 18. That the senate and house of representatives, respectivelv, shall be the sole judges of the elections, returns, and qualifications of their elective members, and each house may determine the rules of its proceedings, punish its members for disorderly behavior, and, with the concurrence of two-thirds, expel an elective member. Both houses shall convene at the capital on the sixteenth day of October next following the election and organize by the election of a speaker or a presiding officer, a clerk, and a sergeant at arms for each house, and such other officers and assistants as may be required. A majority of each house shall constitute a quorum to do business, but a smaller number may meet, adjourn from day to day, and compel the attendance of absent members. The legislature shall hold annual sessions, commencing on the sixteenth day of October, or, if the sixteenth day of October be a legal holiday, then on the first day following which is not a legal holiday, in each year. The legislature may be called in special session at any time by the Governor General for general legislation', or for action on such specific subjects as he may designate. No special session shall continue longer than thirty days, and no regular session shall continue longer than one hundred days, exclusive of Sundays. The legislature is hereby given the power and authority to change the date of the commencement of its annual sessions.

The senators and representatives shall receive an annual compensation for their services, to be ascertained by law, and paid out of the treasury of the Philippine Islands. The senators and representatives shall, in all cases except treason, felony, and breach of the peace, be privileged from arrest during their attendance at the session of their respective houses and in going to and returning from the same; and for any speech or debate in either house they shall not be questioned in any other place.

No senator or representative shall, during the time for which he may have been elected, be eligible to any office the election 
to which is vested in the legislature, nor shall be appointed to any office of trust or profit which shall have been created or the emoluments of which shall have been increased during such term.

SEC. 19. That each house of the legislature shall keep a journal of its proceedings and, from time to time, publish the same; and the yeas and nays of the members of either house, on any question, shall, upon demand of one-fifth of those present, be entered on the journal, and every bill and joint resolution which shall have passed both houses shall, before it becomes a law, be presented to the Governor General. If he approve the same, he shall sign it; but if not, he shall return it with his objections to that house in which it shall have originated, which shall enter the objections at large on its journal and proceed to reconsider it. If, after such reconsideration, two-thirds of the members elected to that house shall agree to pass the same, it shall be sent, together with the objections, to the other house, by which it shall likewise be reconsidered, and if approved by two-thirds of all the members elected to that house it shall be sent to the Governor General, who, in case he shall then not approve, shall transmit the same to the President of the United States. The vote of each house shall be by the yeas and nays, and the names of the members voting for and against shall be entered on the journal. If the President of the United States approve the same, he shall sign it and it shall become a law. If he shall not approve same, he shall return it to the Governor General, so stating, and it shall not become a law: Provided, That if any bill or joint resolution shall not be returned by the Governor General as herein provided within twenty days (Sundays excepted) after it shall have been presented to him the same shall become a law in like manner as if he had signed it, unless the legislature by adjournment prevent its return, in which case it shall become a law unless vetoed by the Governor General within thirty days after adjournment: Provided further, That the President of the United States shall approve or disapprove an act submitted to him under the provisions of this section within six months from and after its enactment and submission for his approval; and if not approved within such time, it shall become a law the same as if it had been specifically approved. The Governor General shall have 
the power to veto any particular item or items of an appropriation bill, but the veto shall not affect the item or items to which he does not object. The item or items objected to shall not take effect except in the manner heretofore provided in this section as to bills and joint resolutions returned to the legislature without his approval.

All laws enacted by the Philippine Legislature shall be reported to the Congress of the United States, which hereby reserves the power and authority to annul the same. If at the termination of any fiscal year the appropriations necessary for the support of government for the ensuing fiscal year shall not have been made, the several sums appropriated in the last appropriation bills for the objects and purposes therein specified, so far as the same may be done, shall be deemed to be reappropriated for the several objects and purposes specified in said last appropriation bill; and until the legislature shall act in such behalf the treasurer shall, when so directed by the Governor General, make the payments necessary for the purposes aforesaid.

SEC. 20. That at the first meeting of the Philippine Legislature created by this Act and trienially thereafter there shall be chosen by the legislature two Resident Commissioners to the United States, who shall hold their office for a term of three years beginning with the fourth day of March following their election, and who shall be entitled to an official recognition as such by all departments upon presentation to the President of a certificate of election by the Governor General of said islands. Each of said Resident Commissioners shall, in addition to the salary and the sum in lieu of mileage now allowed by law, be allowed the same sum for stationery and for the pay of necessary clerk hire as is now allowed to the Members of the House of Representatives of the United States, to be paid out of the Treasury of the United States, and the franking privilege allowed by law to Members of Congress. No person shall be eligible to election as Resident Commissioner who is not a bona fide elector of said islands and who does not owe allegiance to the United States and who is not more than thirty years of age and who does not read and write the English language. The present two Resident Commissioners shall hold office until the fourth of March, nineteen hundred and seventeen. In case of vacancy in the position of Resident Commissioner caused by resignation or otherwise, the 
Governor General may make temporary appointments until the next meeting of the Philippine Legislature, which shall then fill such vacancy; but the Resident Commissioner thus elected shall hold office only for the unexpired portion of the term wherein the vacancy occurred.

SEC. 21. That the supreme executive power shall be vested in an executive officer, whose official title shall be "The Governor General of the Philippine Islands». He shall be appointed by the President, by and with the advice and consent of the Senate of the United States, and hold his office at the pleasure of the President and until his successor is chosen and qualified. The Governor General shall reside in the Philippine Islands during his official incumbency, and maintain his office at the seat of government. He shall, unless otherwise herein provided, appoint, by and with the consent of the Philippine Senate, such officers as may now be appointed by the Governor General, or such as he is authorized by this Act to appoint, or whom he may hereafter be authorized by law to appoint; but appointments made while the senate is not in session shall be effective either until disapproval or until the next adjournment of the senate. $\mathrm{He}$ shall have general supervision and control of all of the departments and bureaus of the government in the Philippine Islands as far as is not inconsistent with the provisions of this Act, and shall be commander in chief of all locally created armed forces and militia. He is hereby vested with the exclusive power to grant pardons and reprieves and remit fines and forfeitures, and may veto any legislation enacted as herein provided. He shall submit within ten days of the opening of each regular session of the Philippine Legislature a budget of receipts and expenditures, which shall be the basis of the annual appropriation bill. He shall commission all officers that he may be authorized to appoint. He shall be responsible for the faithful execution of the laws of the Philippine Islands and of the United States operative within the Philippine Islands, and whenever it becomes necessary he may call upon the commanders of the military and naval forces of the United States in the islands, or summon the posse comitatus, or call out the militia or other locally created armed forces, to prevent or suppress lawless violence, invasion, insurrection, or rebellion; and he may, in case of rebellion or invasion, or imminent danger thereof, when the 
public safety requires it, suspend the privileges of the writ of habeas corpus, or place the islands, or any part thereof, under martial law: Provided, That whenever the Governor General shall exercise this authority, he shall at once notify the President of the United States thereof, together with the attending facts and circumstances, and the President shall have power to modify or vacate the action of the Governor General. He shall annually and at such other times as he may be required make such official report of the transactions of the government of the Philippine Islands to an executive department of the United States to be designated by the President, and his said annual report shall be transmitted to the Congress of the United States; and he shall perform such additional duties and functions as may in pursuance of law be delegated or assigned to him by the President.

SEC. 22. That, except as provided otherwise in this Act, the executive departments of the Philippine government shall continue as now authorized by law until otherwise provided by the Philippine Legislature. When the Philippine Legislature herein provided shall convene and organize, the Philippine Commission, as such, shall cease and determine, and the members thereof shall vacate their offices as members of said commission: Provided, That the heads of executive departments shall continue to exercise their executive functions until the heads of departments provided by the Philippine Legislature pursuant to the provisions of this Act are appointed and qualified. The Philippine Legislature may thereafter by appropriate legislation increase the number or abolish any of the executive departments, or make such changes in the names and duties thereof as it may see fit, and shall provide for the appointment and removal of the heads of the executive departments by the Governor General: Provided, That all executive functions of the government must be directly under the Governor General or within one of the executive departments under the supervision and control of the Governor General. There is hereby established a bureau, to be known as the Bureau of Non-Christian tribes, which said bureau shall be embraced in one of the executive departments to be designated by the Governor General, and shall have general supervision over the public affairs of the inhabitants of the territory represented in the legislature by appointive senators and representatives. 
SEC. 23. That there shall be appointed by the President, by and with the advice and consent of the Senate of the United States, a vice governor of the Philippine Islands, who shall have all of the powers of the Governor General in the case of a vacancy or temporary removal, resignation, or disability of the Governor General, or in case of his temporary absence; and the said vice governor shall be the head of the executive department, known as the department of public instruction, which shall include the bureau of education and the bureau of health, and he may be assigned such other executive duties as the Governor General may designate.

Other bureaus now included in the department of public instruction shall, until otherwise provided by the Philippine Legislature, be included in the department of the interior.

The President may designate the head of an executive department of the Philippine government to act as Governor General in the case of a vacancy, the temporary removal, resignation, or disability of the Governor General and the vice governor, or their temporary absence, and the head of the department thus designated shall exercise all the powers and perform all the duties of the Governor General during such vacancy, disability, or absence.

SEC. 24. That there shall be appointed by the President an auditor, who shall examine, audit, and settle all accounts pertaining to the revenues and receipts from whatever source of the Philippine government and of the provincial and municipal governments of the Philippines, including trust funds and funds derived from bond issues; and audit, in accordance with law and administrative regulations, all expenditures of funds or property pertaining to or held in trust by the government or the Provinces or municipalities thereof. He shall perform a like duty with respect to all government branches.

He shall keep the general accounts of the government and preserve the vouchers pertaining thereto.

It shall be the duty of the auditor to bring to the attention of the proper administrative officer expenditures of funds or property which, in his opinion, are irregular, unnecessary, excessive, or extravagant.

There shall be a deputy auditor appointed in the same manner as the auditor. The deputy auditor shall sign such official papers as the auditor may designate and perform such other duties as the auditor may prescribe, and in case of the death, resignation, 
sickness, or other absence of the auditor from his office, from any cause, the deputy auditor shall have charge of such office. In case of the absence from duty, from any cause, of both the auditor and the deputy auditor, the Governor General may designate an assistant, who shall have charge of the office.

The administrative jurisdiction of the auditor over accounts, whether of funds or property, and all vouchers and records pertaining thereto, shall be exclusive. With the approval of the Governor General he shall from time to time make and promulgate general or special rules and regulations not inconsistent with law covering the method of accounting for public funds and property, and funds and property held in trust by the government or any of its branches: Provided, That any officer accountable for public funds or property may require such additional reports or returns from his subordinates or others as he may deem necessary for his own information and protection.

The decisions of the auditor shall be final and conclusive upon the executive branches of the government, except that appeal therefrom may be taken by the party aggrieved or the head of the department concerned within one year, in the manner hereinafter prescribed. The auditor shall, except as hereinafter provided, have like authority as that conferred by law upon the several auditors of the United States and the Comptroller of the United States Treasury and is authorized to communicate directly with any person having claims before him for settlement, or with any department, officer, or person having official relations with his office.

As soon after the close of each fiscal year as the accounts of said year may be examined and adjusted the auditor shall submit to the Governor General and the Secretary of War an annual report of the fiscal concerns of the government, showing the receipts and disbursements of the various departments and bureaus of the government and of the various Provinces and municipalities, and make such other reports as may be required of him by the Governor General tor the Secretary of War.

In the execution of their duties the auditor and the deputy auditor are authorized to summon witnesses, administer oaths, and to take evidence, and, in the pursuance of these provisions, may issue subpoenas and enforce the attendance of witnesses, as now provided by law. 
The office of the auditor shall be under the general supervision of the Governor General and shall consist of the auditor and deputy auditor and such necessary assistants as may be prescribed by law.

SEC. 25. That any person aggrieved by the action or decision of the auditor in the settlement of his account or claim may, within one year, take an appeal in writing to the Governor General, which appeal shall specifically set forth the particular action of the auditor to which exception is taken, with the reason and authorities relied on for reversing such decision.

If the Governor General shall confirm the action of the auditor, he shall so indorse the appeal and transmit it to the auditor, and the action shall thereupon be final and conclusive. Should the Governor General fail to sustain the action of the auditor, he shall forthwith transmit his grounds of disapproval to the Secretary of War, together with the appeal and the papers necessary to a proper understanding of the matter. The decision of the Secretary of War in such case shall be final and conclusive.

SEC. 26. That the supreme court and the courts of first instance of the Philippine Islands shall possess and exercise jurisdiction as heretofore provided and such additional jurisdiction as shall hereafter be prescribed by law. The municipal courts of said islands shall possess and exercise jurisdiction as now provided by law, subject in all matters to such alteration and amendment as may be hereafter enacted by law; and the chief justice and associate justices of the supreme court shall hereafter be appointed by the President, by and with the advice and consent of the United States. The judges of the court of first instance shall be appointed by the Governor General, by and with the advice and consent of the Philippine Senate: Provided, That the admiralty jurisdiction of the supreme court and courts of first instance shall not be changed except by Act of Congress. That in all cases pending under the operation of existing laws, both criminal and civil, the jurisdiction shall continue until final judgment and determination.

SEC. 27. That the Supreme Court of the United States shall have jurisdiction to review, revise, reverse, modify, or affirm the final judgments and decrees of the Supreme Court of the Philippine Islands in all actions, cases, causes, and proceedings now pending therein or hereafter determined thereby in which the Constitution 
or any statute, treaty, title, right, or privilege of the United States is involved, or in causes in which the value in controversy exceeds $\$ 25,000$, or in which the title or possession of real estate exceeding in value the sum of $\$ 25,000$, to be ascertained by the oath of either party or of other competent witnesses, is involved or brought in question; and such final judgments or decrees may and can be reviewed, revised, reversed, modified, or affirmed by said Supreme Court of the United States on appeal or writ of error by the party aggrieved within the same time, in the same manner, under the same regulations, and by the same procedure, as far applicable, as the final judgments and decrees of the district courts of the United States.

SEC. 28. That the government of the Philippine Islands may grant franchises and rights, including the authority to exercise the right of eminent domain, for the construction and operation of works of public utility and service, and may authorize said works to be constructed and maintained over and across the public property of the United States, including streets, highways, squares, and reservations, and over similar property of the government of said islands, and may adopt rules and regulations under which the provincial and municipal governments of the islands may grant the right to use and occupy such public property belonging to said Provinces or municipalities: Frovided, That no private property shall be damaged or taken for any purpose under this section without just compensation, and that such authority to take and occupy land shall not authorize the taking, use, or occupation of any land except such as is required for the actual necessary purposes for which the franchise is granted, and that no franchise or right shall be granted to any individual, firm, or corporation except under the conditions that it shall be subject to amendment, alteration, or repeal by the Congress of the United States, and that lands or right of use and occupation of lands thus granted shall revert to the governments by which they were respectively granted upon the termination of the franchises and rights under which they were granted or upon their revocation or repeal. That all franchises or rights granted under this Act shall forbid the issue of stock or bonds except in exchange for actual cash or for property at a fair valuation equal to the par value of the stock or bonds so issued; shall forbid the declaring of stock or bond dividends, 
and, in the case of public-service corporations, shall provide for the effective regulation of the charges thereof, for the official inspection and regulation of the books and accounts of such corporations, and for the payment of a reasonable percentage of gross earnings into the treasury of the Philippine Islands or of the Province or municipality within which such franchises are granted and exercised: Provided further, That it shall be unlawful for any corporation organized under this Act, or for any person, eompany, or corporation receiving any grant, franchise, or concession from the government of said islands, to use, employ, or contract for the labor of persons held in involuntary servitude; and any person, company, or corporation so violating the provisions of this Act shall forfeit all charters, grants, or franchises for doing business in said islands, in an action or proceeding brought for that purpose in any court of competent jurisdiction by any officer of the Philippine government, or on the complaint of any citizen of the Philippines, under such regulations and rules as the Philippine Legislature shall prescribe, and in addition shall be deemed guilty of an offense, and shall be punished by a fine of not more than $\$ 10,000$.

SEc. 29. That, except as in this Act otherwise provided, the salaries of all the officials of the Philippines not appointed by the President, including deputies, assistants, and other employees, shall be such and be so paid out of the revenues of the Philippines as shall from time to time be determined by the Philippine Legislature; and if the legislature shall fail to make an appropriation for such salaries, the salaries so fixed shall be paid without the necessity of further appropriations therefor. The salaries of all officers and all expenses of the offices of the various officials of the Philippines appointed as herein provided by the President shall also be paid out of the revenues of the Philippines. The aunual salaries of the following-named officials appointed by the President and so to be paid shall be: The Governor General, $\$ 18,000$; in addition thereto he shall be entitled to the occupancy of the buildings heretofore used by the chief executive of the Philippines, with the furniture and effects therein, free of rental; vice governor, $\$ 10,000$; chief justice of the supreme court, $\$ 8,000$; associate justices of the supreme court, $\$ 7,500$ each; auditor, $\$ 6,000$; deputy auditor, $\$ 3,000$.

SEC. 30. That the provisions of the foregoing section shall D1. 75 
not apply to provincial and municipal officials; their salaries and the compensation of their deputies, assistants, and other help, as well as all other expenses incurred by the Provinces and municipalities, shall be paid out of the provincial and municipal revenues in such manner as the Philippine Legislature shall provide.

SEC. 31. That all laws or parts of laws applicable to the Philippines not in conflict with any of the provisions of this Act are hereby continued in force and effect.

Approved, August 29, 1916. 